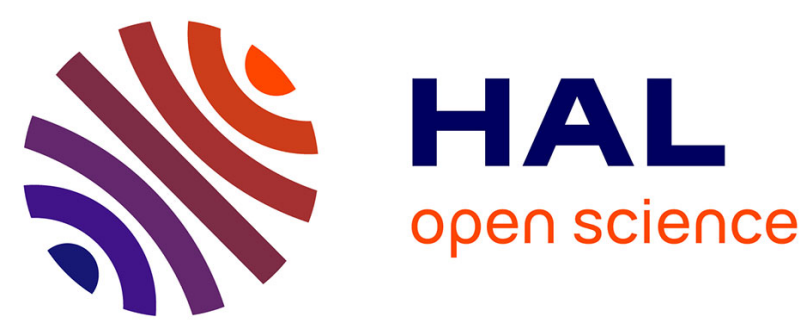

\title{
Permanent Magnet Synchronous Machines: Performances during Driving Cycles for a Hybrid Electric Vehicle Application
}

\author{
Phi Hung Nguyen, Emmanuel Hoang, Mohamed Gabsi
}

\section{To cite this version:}

Phi Hung Nguyen, Emmanuel Hoang, Mohamed Gabsi. Permanent Magnet Synchronous Machines: Performances during Driving Cycles for a Hybrid Electric Vehicle Application. IEEE-ISIE2010 International Symposium on Industrial Electronics 2010, Jul 2010, Bari, Italy. hal-00515620v2

\section{HAL Id: hal-00515620 \\ https://hal.science/hal-00515620v2}

Submitted on 7 Sep 2010

HAL is a multi-disciplinary open access archive for the deposit and dissemination of scientific research documents, whether they are published or not. The documents may come from teaching and research institutions in France or abroad, or from public or private research centers.
L'archive ouverte pluridisciplinaire HAL, est destinée au dépôt et à la diffusion de documents scientifiques de niveau recherche, publiés ou non, émanant des établissements d'enseignement et de recherche français ou étrangers, des laboratoires publics ou privés. 


\title{
Permanent Magnet Synchronous Machines: Performances during Driving Cycles for a Hybrid Electric Vehicle Application
}

\author{
Phi Hung NGUYEN ${ }^{1}$, Student Member, IEEE, Emmanuel HOANG ${ }^{1}$, Mohamed GABSI ${ }^{1}$, Member, IEEE, \\ Luc KOBYLANSKI ${ }^{2}$ and Dominique CONDAMIN ${ }^{3}$ \\ ${ }^{1}$ SATIE, ENS Cachan, CNRS, UniverSud, 61 av Président Wilson, F-94230 Cachan, France \\ ${ }^{2}$ VALEO Systèmes Electriques, 2 rue André Boulle, 94046 Créteil, France \\ ${ }^{3}$ MOTEURS LEROY-SOMER, Boulevard Marcellin Leroy, 16015 Angoulême Cedex, France \\ E-mail: pnguyen@satie.ens-cachan.fr
}

\begin{abstract}
This paper presents the comparison of three permanent magnet synchronous machines (PMSMs) with concentrated flux, the first two machines with fractional slot windings and the other with distributed windings considered as the reference machine. Therefore, the advantages of PMSMs with fractional slot windings were showed. Then, the computation method of the average copper losses, the average iron losses and the average flux weakening copper losses during the driving cycle of a hybrid electric vehicle (HEV) was presented. Finally, a comparative study during the driving cycles of three machines gives a global view of machine performances assembled for a HEV application.
\end{abstract}

Index Terms-PMSM, concentrated flux, fractional slot windings, hybrid electric vehicle.

\section{INTRODUCTION}

The hybrid electric vehicle allows combining the advantages of the thermal and the electrical motorization while minimizing their disadvantages [1]-[2]. That is why several researchers have studied novel technologies of electrical machines for this kind of application such as the asynchronous machine, synchronous machine, switched reluctance machine or switching-flux synchronous machine [2]-[6]. This paper presents an electrical motorization of HEV by three types of driving cycle: NEDC, Artemis_Urban and Artemis_Road. Then, we were interested to study PMSM with concentrated flux for these cases.

The three machines presented in this paper content:

1) The machine with 12 slots and 8 poles, with concentrated and fractional slot windings (Fig.1.a.).

2) The machine with 12 slots and 16 poles, with concentrated and fractional slot windings (Fig.1.b.).

3) The machine 48 slots and 8 poles, with distributed windings (Fig.2.) considered as the reference machine.

The comparative study of the three machines in terms of average losses during the driving cycles of vehicle is the particular point of this paper. It presents the computation method of the average copper losses and the average iron losses of three machines for three driving cycles of vehicle.
Thus, this study gives the performances of the PMSM with concentrated flux and fractional slot windings. All the computation and modelling are based on the finite element analysis (FEA-2D) with non-linear magnetic material.

\section{STRUCTURES}

The first machine presented in this paper is a PMSM with concentrated flux, concentrated and fractional slot windings. In this case, there are $8 \mathrm{PMs}$ on the rotor and 12 slots on the stator (Fig.1.a.). Thus, it was called fractional slot windings because the slot per pole and per phase number is of $S_{p p}=1 / 2$ [1]-[3], [6]-[7]:

$$
S_{p p}=\frac{S}{p^{*} q}
$$

where:

S: slot number.

p: pole number.

q: phase number.

TABLE I

GeOMETRIC DATA OF THE THREE MACHINES

\begin{tabular}{lccc}
\hline \hline Parameters & $48-8$ & $12-8$ & $12-16$ \\
\hline Pole number, $\mathrm{p}$ & 8 & 8 & 16 \\
Slot number, $\mathrm{S}$ & 48 & 12 & 12 \\
Slot per pole and per phase number, $\mathrm{S}_{\mathrm{pp}}$ & 2 & $1 / 2$ & $1 / 4$ \\
Radius of air-gap, mm & 70 & 68 & 70 \\
Stator external diameter, mm & 200 & 200 & 200 \\
Stack length, mm & 200 & 200 & 200 \\
Air-gap length, mm & 0.6 & 0.6 & 0.6 \\
Shaft diameter, mm & 30 & 30 & 30 \\
Remanent flux density $\mathrm{B}_{\mathrm{r}}$, T & 1.2 & 1.2 & 1.2 \\
Thickness of magnet at air-gap level, mm & 5.2 & 5.2 & 5.2 \\
Thickness of magnet at axis level, mm & 8.8 & 8.8 & 8.8 \\
Magnet height, mm & 35 & 33 & 35 \\
\hline \hline
\end{tabular}

The second machine was developed by doubling the pole number on the rotor. Therefore, we have obtained the PMSM 
with 16PMs on the rotor, so that the slot per pole and per phase number is of $\mathrm{S}_{\mathrm{pp}}=1 / 4$ (Fig.1.b.). Then, the third machine was considered as the reference machine that was characterized by the distributed windings with 48 slots and 8 poles on the rotor (Fig.2.). These three machines have the same envelope limited by the industrial application such as the stator external diameter and the stack length.

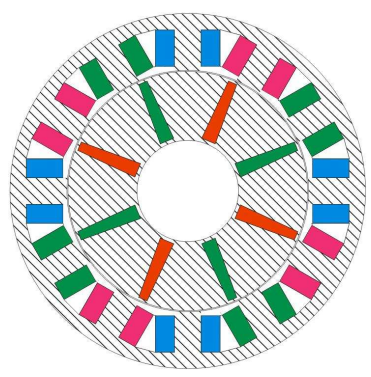

(a)

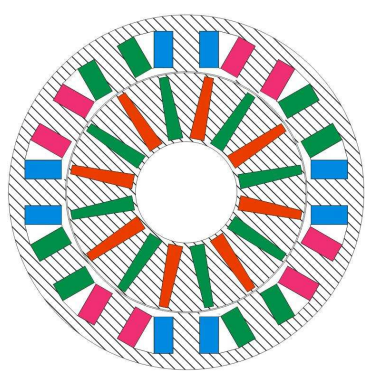

(b)
Fig.1. Machine with concentrated and fractional slot windings, (a) 12 slots and 8 poles and (b) 12 slots and 16 poles.

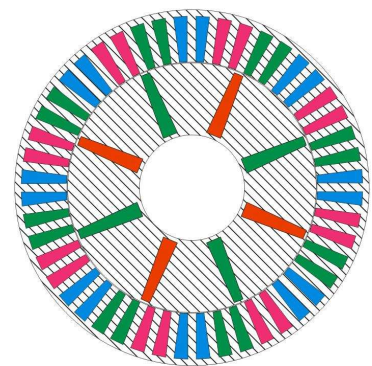

Fig.2. Machine with distributed windings with 48 slots and 8 poles.

In order to better understand the performance of PMSMs with fractional slot windings, we have made the first comparison of three machines for the same root mean square (RMS) current density. This comparison was based on the flux and on the torque during the electric period of each machine.

The torque $\mathrm{T}$ depends on the pole number $\mathrm{p}$, the RMS value of flux fundamental $\Phi$ and the RMS value of injected current I by the following expression [8-10]:

$$
T=\frac{3}{2} \cdot p \cdot \Phi \cdot I
$$

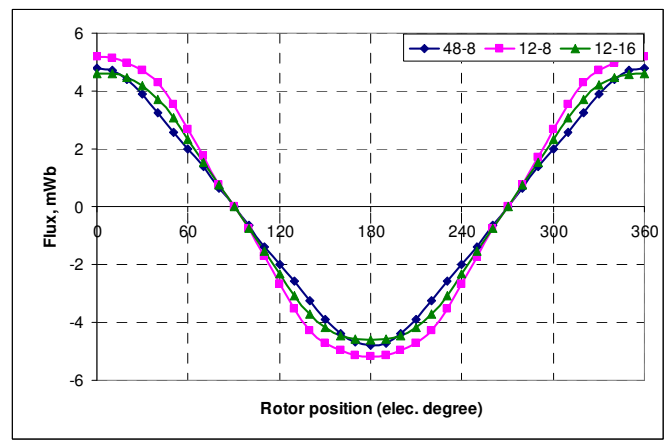

Fig.3. Instantaneous flux during the electric period of the three machines.

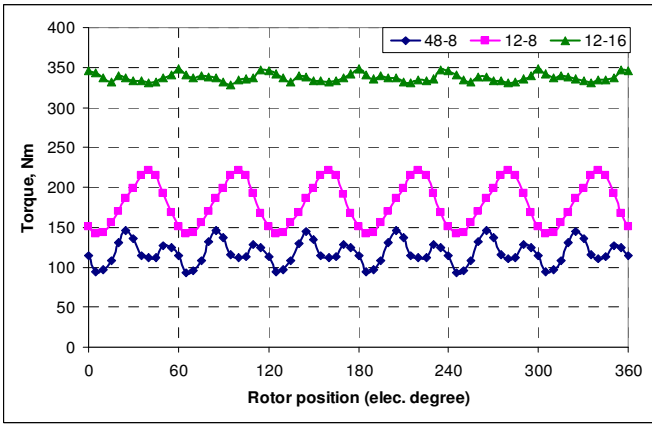

Fig.4. Instantaneous torque during the electric period of the three machines.

According to Fig.3, the 12-8 machine gives the highest value of flux at no-load among the three machines. Thus, for the same RMS value of injected current density $\delta=10 \mathrm{~A} / \mathrm{mm}^{2}$ and the same pole number, the average torque of this machine is higher than the 48-8 machine (Table II). However, with two times more of pole numbers, the 12-16 machine nearly gives twice higher of average torque than the 12-8 machine. The reason of the difference between these machines is that the flux form which can give the different value of flux fundamental, hence the different value of average torque during the electric period of machines.

TABLE II

FIRST COMPARISON RESULT

\begin{tabular}{cccc}
\hline \hline Parameters & $48-8$ & $12-8$ & $12-16$ \\
\hline Average torque, $\mathrm{Nm}$ & 128 & 185 & 343 \\
Flux at no-load, mWb & 4.8 & 5.2 & 4.6 \\
\hline \hline
\end{tabular}

This preliminary result has shown the interests of PMSMs with fractional slots windings. It is the possibility to give a very high electromagnetic torque and to reduce the torque ripple of machine, especially the 12-16 machine (Fig.4.). Consequently, to produce the same torque, the copper losses will be lower (Fig.5.). However, the fact of the higher alimentation frequency may give higher iron losses.

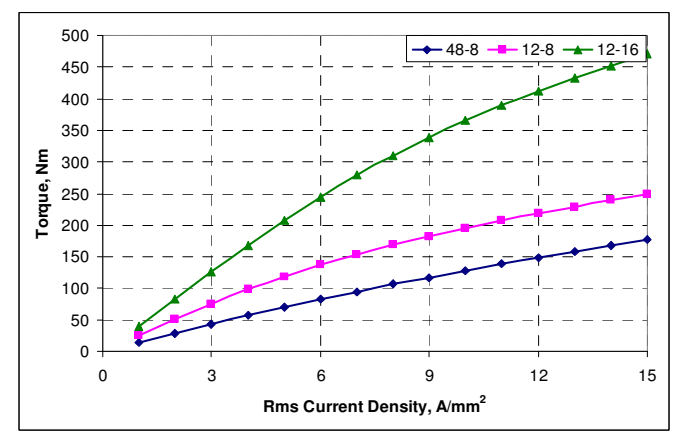

Fig.5. Torque versus RMS current density for the three machines.

In the following part, basing on point of view of losses, we were interested to study the performance of all these machines during the driving cycles of the vehicle. Thus, it will show advantages of machine with fractional slot windings and give the global view of machine performances for this application. 
III. Computation Method of the AVERAge Losses DURING THE DRIVING CYCLE OF VEHICLE

In several studies on electric machines for hybrid transport application [1]-[2], [7]-[9], we have found that the computation is principally made for some particular points of the driving cycle, such as the based point or the point of high speed. Therefore, for this study, our interest is particularly in the determination of the average losses during the driving cycles of a HEV. The interest of this computation is to give a total view of the optimization during the driving cycles of the vehicle.

In this paper, for a HEV, there are three driving cycles, called NEDC (Fig.6.a.), Artemis_Urban (Fig.6.b.) and Artemis_Road (Fig.6.c.), respectively.

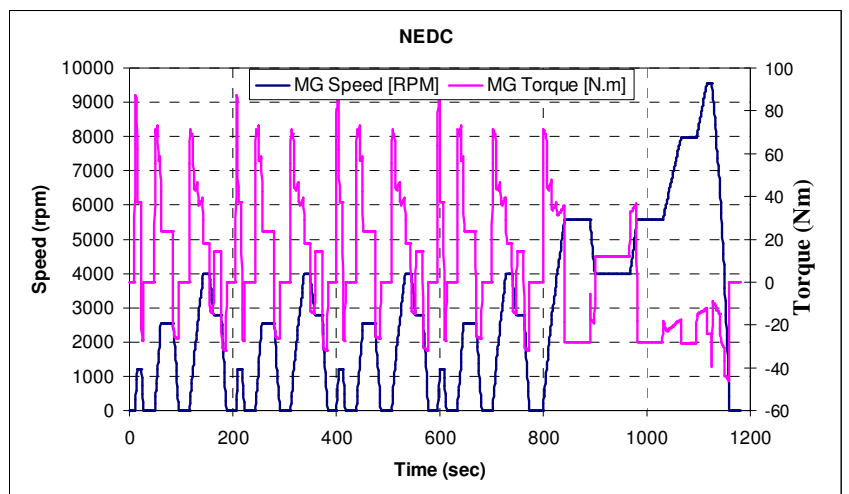

Fig.6.a. NEDC driving cycle of the HEV.

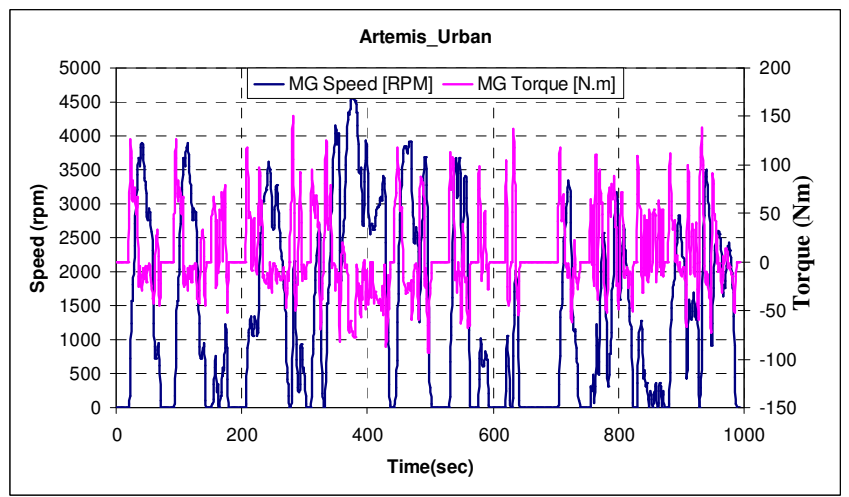

Fig.6.b. Artemis_Urban driving cycle of the HEV.

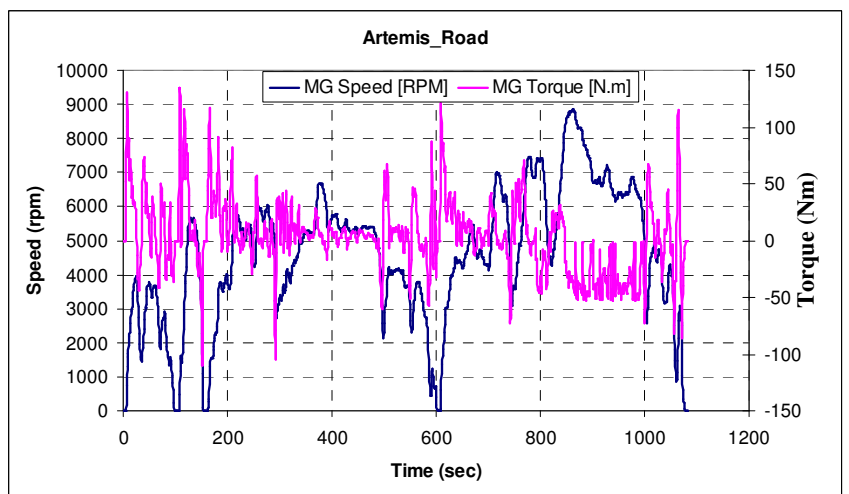

Fig.6.c. Artemis_Road driving cycle of the HEV.
Analyzing three driving cycles and basing on the particular point of $200 \mathrm{Nm}$ torque and of $1820 \mathrm{rpm}$ speed, we have the important parameters such as the maximum torque, the maximum speed, the maximum power and the average power during the cycle, the number of points where the speed is superior to $1820 \mathrm{rpm}$. The point of $200 \mathrm{Nm}$ torque and of $1820 \mathrm{rpm}$ speed, called the based point, is the point determinated by the possibility to attain the normal drive of machine during all the three cycles.

TABLE III

IMPORTANT PARAMETERS OF THREE DRIVING CYCLES OF VEHICLE

\begin{tabular}{cccc}
\hline \hline & NEDC & Artemis_Urban & Artemis_Road \\
\hline Maximum torque, Nm & 90 & 150 & 135 \\
Maximum speed, rpm & 9600 & 4600 & 8900 \\
Average speed, rpm & 2700 & 1000 & 4500 \\
Maximum power, $\mathrm{kW}$ & 40 & 37 & 45 \\
Average power, $\mathrm{kW}$ & 6.5 & 4.5 & 10.5 \\
Point number with speed & $685 / 1181$ & $373 / 994$ & $968 / 1083$ \\
$>1820 \mathrm{rpm}$ & $58 \%$ & $37 \%$ & $90 \%$ \\
\hline \hline
\end{tabular}

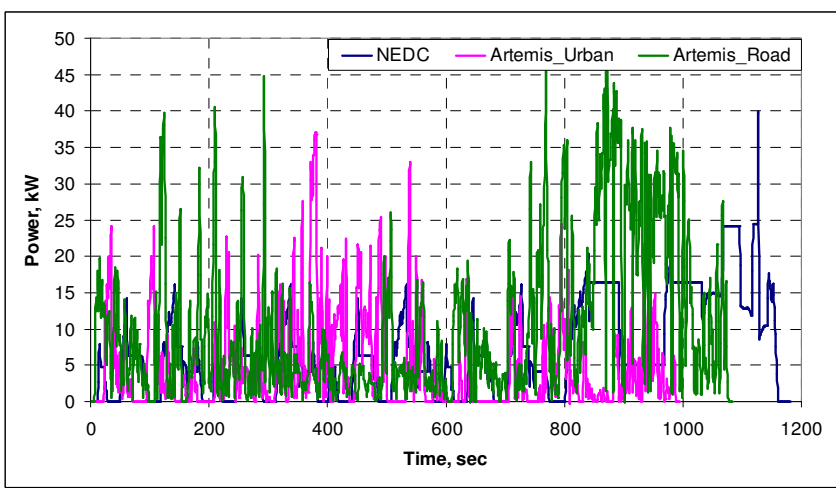

Fig.7. Instantaneous power during the three cycles.

Fig.7 and Table III have shown that there are some points that can attain power of $45 \mathrm{~kW}$ but the values of average power during the cycles are of $6.39 \mathrm{~kW}, 4.37 \mathrm{~kW}$ and $10.48 \mathrm{~kW}$ for the cycles NEDC, Artemis_Urban and Artemis_Road, respectively.

\section{A. Torque Model}

From the curves in Fig.5, we have established the model of the average torque according to the RMS current density as following:

$$
T=k_{t 1} \cdot \frac{\delta}{10}-k_{t 2} \cdot\left(\frac{\delta}{10}\right)^{2}
$$

where $\mathrm{k}_{\mathrm{t} 1}, \mathrm{k}_{\mathrm{t} 2}$ are the constants and $\delta$ is RMS current density in $\mathrm{A} / \mathrm{mm}^{2}$. For the three studied machines, we have found their value shown in Table IV.

\section{TABLE IV}

TORQUE MODEL CONSTANTS

\begin{tabular}{cccc}
\hline \hline Constants & $48-8$ & $12-8$ & $12-16$ \\
\hline $\mathrm{k}_{\mathrm{t} 1}$ & 148 & 251 & 454 \\
$\mathrm{k}_{\mathrm{t} 2}$ & 17 & 54 & 91 \\
\hline \hline
\end{tabular}


B. Copper Losses During The Cycle

From the Joule Effect, the copper losses model is determinated by:

$$
L_{c o}=\rho_{c o} \cdot L_{a} \cdot\left(k_{s} \cdot S_{s} \cdot N_{s}\right) \cdot \delta^{2}
$$

where:

$\rho_{c o}:$ copper resistivity, $\Omega m$.

$\mathrm{L}_{\mathrm{a}}$ : stack length, $\mathrm{mm}$.

$\mathrm{k}_{\mathrm{s}}$ : slot fill factor.

$\mathrm{N}_{\mathrm{s}}$ : slot number.

$\mathrm{S}_{\mathrm{s}}$ : slot section, $\mathrm{mm}^{2}$.

The calculation method of average copper losses during the cycle is shown in the Fig.8. Each point on the cycle gives the value of torque, then, the model (3) gives the RMS value of current density to attain this torque value. Then, knowing this value, the equation (4) gives the value of copper losses for this point. Consequently, the average value of copper losses is determinated during the cycle (Table V).

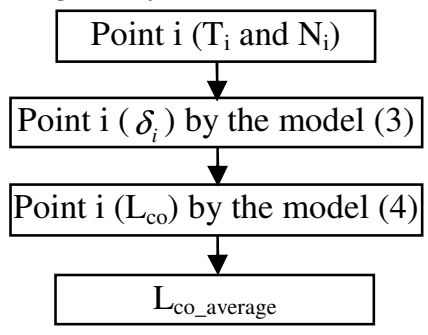

Fig.8. Computation method of average copper losses during the cycle.

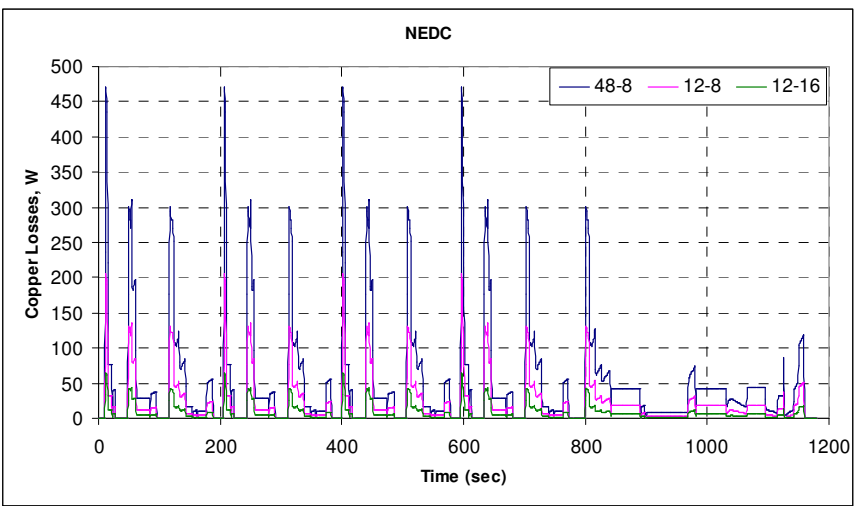

Fig.9.a. Copper losses for the NEDC driving cycle.

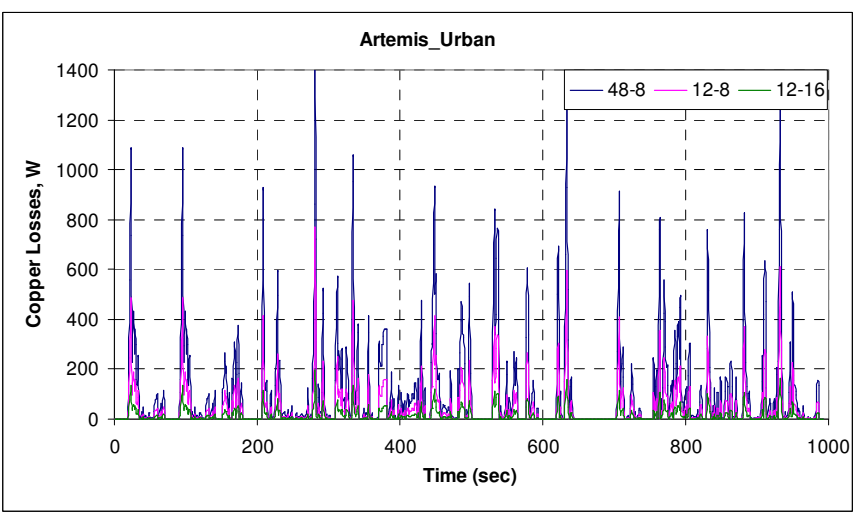

Fig.9.b. Copper losses for the Artemis_Urban driving cycle.

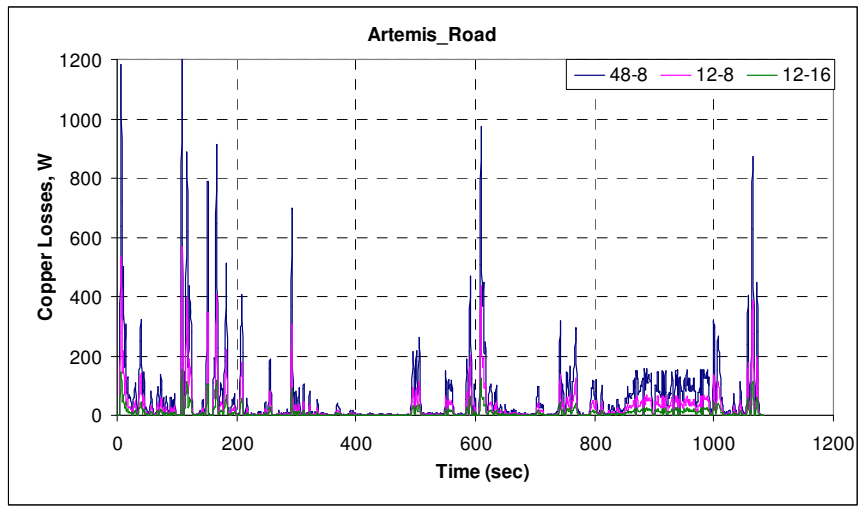

Fig.9.c. Copper losses for the Artemis_Road driving cycle.

TABLE V

Average Copper Losses Result

\begin{tabular}{cccc}
\hline \hline Average copper losses, W & $48-8$ & $12-8$ & $12-16$ \\
\hline NEDC & 50 & 22 & 10 \\
Artemis_Urban & 102 & 44 & 16 \\
Artemis_Road & 63 & 27 & 11 \\
\hline \hline
\end{tabular}

C. Iron Losses During The Cycle

Based on the assumption that the values of iron losses at load are the same values of that at no-load, we have computed the iron losses only at the presence of permanent magnets and on the stator. The iron losses are made up of two parts: losses by hysterisis and losses by eddy current [9]-[10]. We have proposed the following iron losses $(\mathrm{W} / \mathrm{kg}$ ) model:

$$
L_{\text {iron }}=L_{\text {hys }}+L_{E C}
$$

$$
L_{\text {iron }}=\left(k_{h 1} * \Delta \mathrm{B}+k_{h 2} * \Delta \mathrm{B}^{2}\right) * f+\alpha_{p} \frac{1}{T} \int_{0}^{T}\left(\frac{d b}{d t}\right)^{2} \cdot d t
$$

where:

$f=\frac{p}{2} * \frac{N}{60}:$ frequency, $\mathrm{Hz}$.

$\mathrm{N}$ : speed, rpm.

$\Delta B$ : maximum ripple of flux density, $\mathrm{T}$.

$\mathrm{k}_{\mathrm{h} 1}, \mathrm{k}_{\mathrm{h} 2}, \alpha_{p}$ : coefficients whose values have been determinated from the constructor data. In fact, we have calculated and obtained these values: $\mathrm{k}_{\mathrm{h} 1}=0\left(\mathrm{~A} \cdot \mathrm{m}^{-1}\right), \mathrm{k}_{\mathrm{h} 2}=50\left(\mathrm{~A} \cdot \mathrm{m} \cdot \mathrm{V}^{-1} \cdot \mathrm{s}^{-1}\right)$ and $\alpha_{p}=0.042\left(\mathrm{~A} \cdot \mathrm{m} \cdot \mathrm{V}^{-1}\right)$.

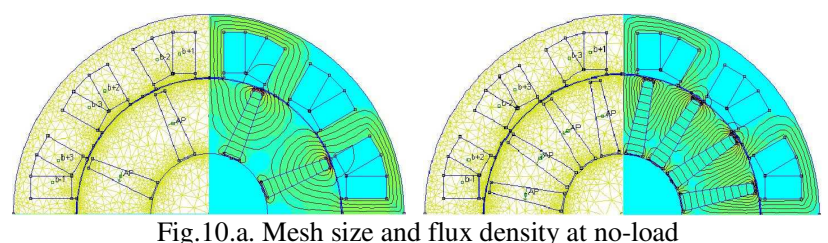

Fig.10.a. Mesh size and flux density at no-load for the two machines $12-8$ and 12-16.

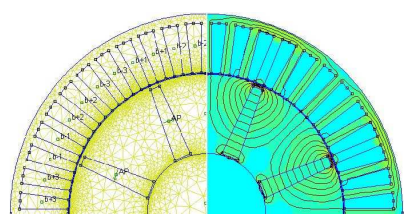

Fig.10.b. Mesh size and flux density at no-load for the 48-8 machine. 
In order to have a better result, the stator of each machine was divided by several small subdivisions in which the value of flux density is nearly constant (Fig.11.).

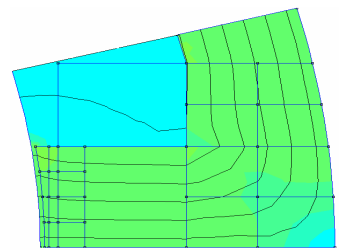

Fig.11. Subdivisions in the haft of stator tooth for the 12-8 machine.

The calculation method of average iron losses during the driving cycle was separated by two parts: losses by hysteresis and by eddy current. Knowing the peak-to-peak value of flux density and the volume of each subdivision, we could deduce the iron losses by hysteresis for each point on the cycle by the first part of model (6) basing on the frequency or the speed of this point. Then, knowing the value of flux density variation at the corresponding rotor position, we could deduce the iron losses by eddy current for each point on the driving cycle by the second part of model (6). Consequently, we could determinate the average value of iron losses during the driving cycle of vehicle. The results are presented in Fig.12 and Table VI.

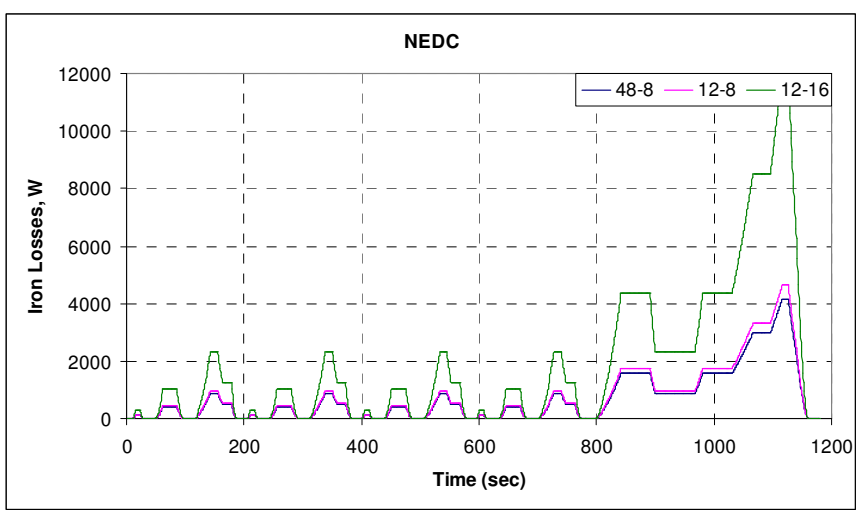

Fig.12.a. Iron losses for the NEDC driving cycle.

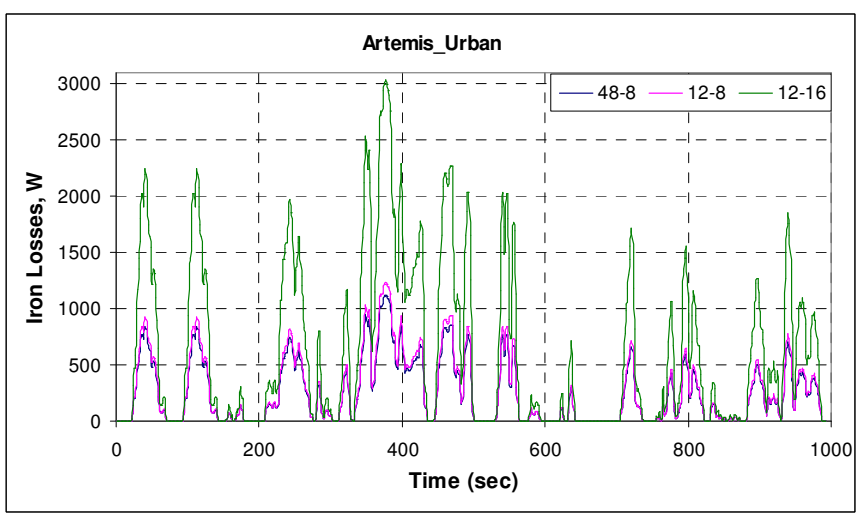

Fig.12.b. Iron losses for the Artemis_Urban driving cycle.

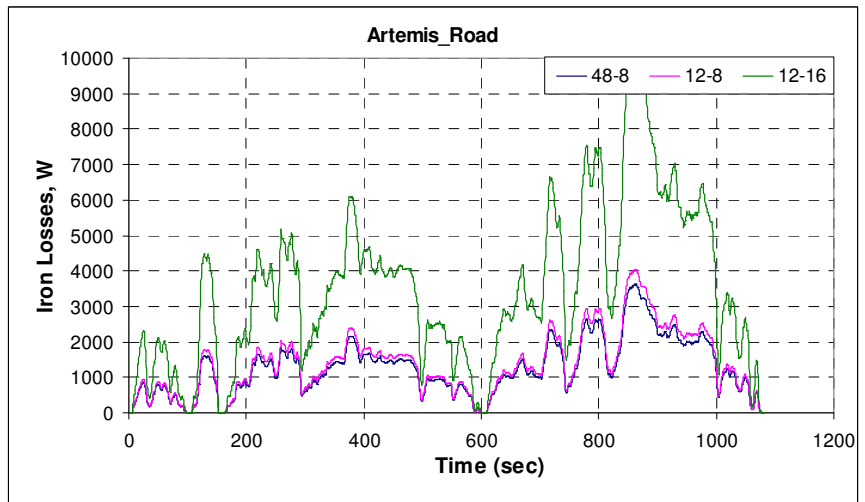

Fig.12.c. Iron losses for the Artemis_Road driving cycle.

TABLE VI

AVERAGE IRON LOSSES RESULT

\begin{tabular}{cccc}
\hline \hline Average iron losses, W & $48-8$ & $12-8$ & $12-16$ \\
\hline NEDC & 690 & 760 & 1886 \\
Artemis_Urban & 241 & 262 & 610 \\
Artemis_Road & 1260 & 1391 & 3477 \\
\hline \hline
\end{tabular}

D. Flux Weakening Copper Losses During The Cycle

According to Fig.6 and Table III, the torque-speed characteristic of the three driving cycles of HEV has shown that there are points where the speed is superior of the based speed of 1820rpm. Thus, the machine flux must be weakened at these points to obtain the desired speeds [11]-[13]. Therefore, we have separated copper losses in two parts: one called copper losses du to the q-axis current that gives the torque value of points during the driving cycle, the other called the flux weakening copper losses du to the $d$-axis current of the points where the speed is superior to 1820rpm. The objective of this separation is to show the flux weakening contribution during the driving cycle of the vehicle.

The proposed model of flux weakening current density is:

$$
\delta_{\text {flux weakening }}=\delta_{s c} \cdot\left(1-\frac{N_{\text {based }}}{N}\right) \text { if } \mathrm{N}>\mathrm{N}_{\text {based }}
$$

where: $\delta_{s c}$ is the short-circuit RMS current density. It is the RMS value of injected current to give the back-EMF value equaling zero, so that the flux is totally weakened. Then, this current is the current on the $d$-axis (Fig.13.).
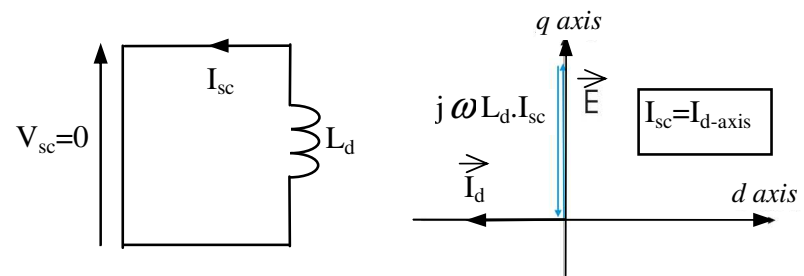

Fig.13. Flux weakening current effect in machines.

TABLE VII

SHORT-CIRCUIT RMS CURRENT DENSITY

\begin{tabular}{cccc}
\hline \hline Sort-circuit RMS current density & $48-8$ & $12-8$ & $12-16$ \\
\hline$\delta_{s c}, \mathrm{~A} / \mathrm{mm}^{2}$ & 14.6 & 8.2 & 8.9 \\
\hline \hline
\end{tabular}




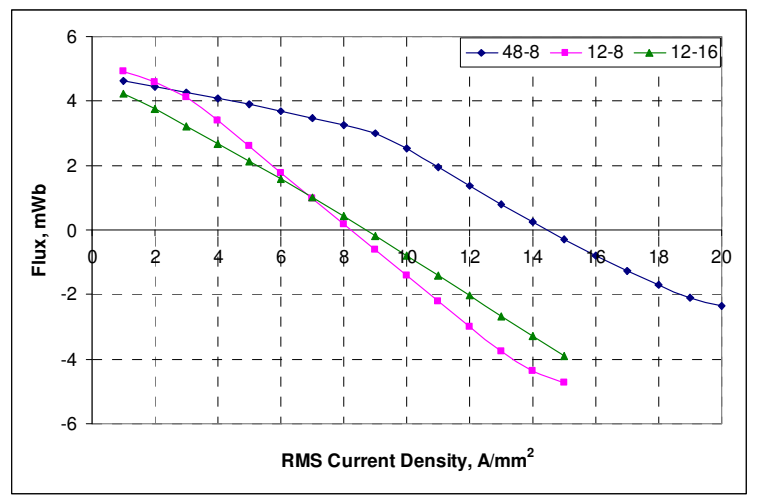

Fig.14. Short-circuit current density for the three machines.

According to Fig.14, we have found that the two machines with concentrated windings are easier for the flux weakening while the 48-8 machine needs a very high current for the flux weakening.

From the Table III, we have found that the vehicle works the important time part for the flux weakening, especially for the NEDC and Artemis_Road driving cycles, 58\% and 89.4\% respectively. Therefore, the flux weakening copper losses gives an important part for the machine efficiency during the cycles.

The calculation method of average flux weakening copper losses during the cycle is the same as for average copper losses during the cycle, shown by model (4) and Fig.8. The difference is the computation applied only for the points where the speed is superior to 1820rpm and for the rest, there isn't flux weakening effect.

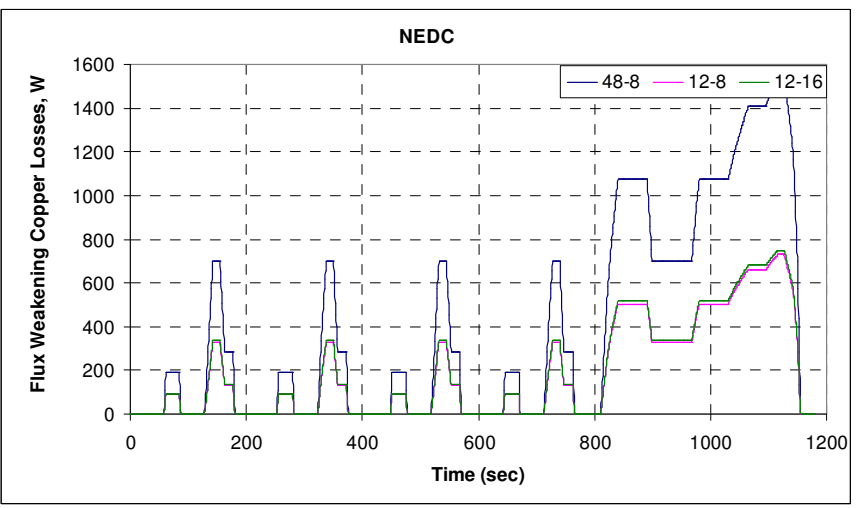

Fig.15.a. Flux weakening copper losses for the NEDC driving cycle.

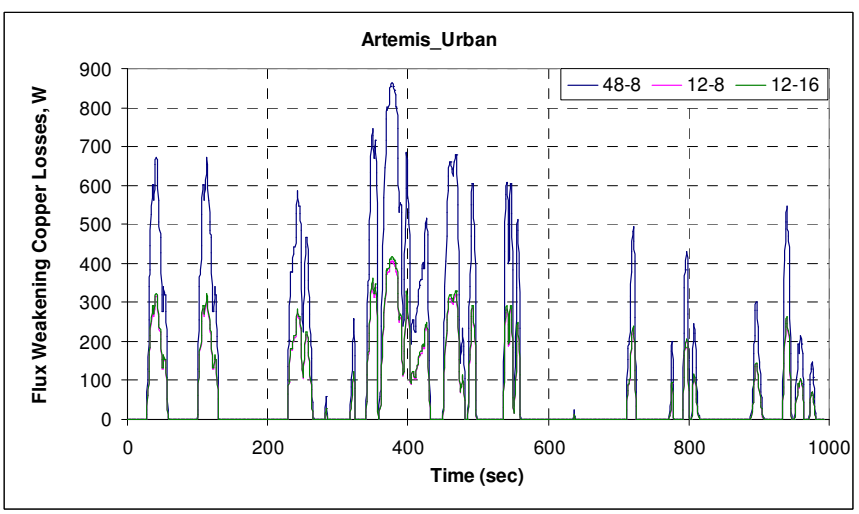

Fig.15.b. Flux weakening copper losses for the Artemis_Urban driving cycle.

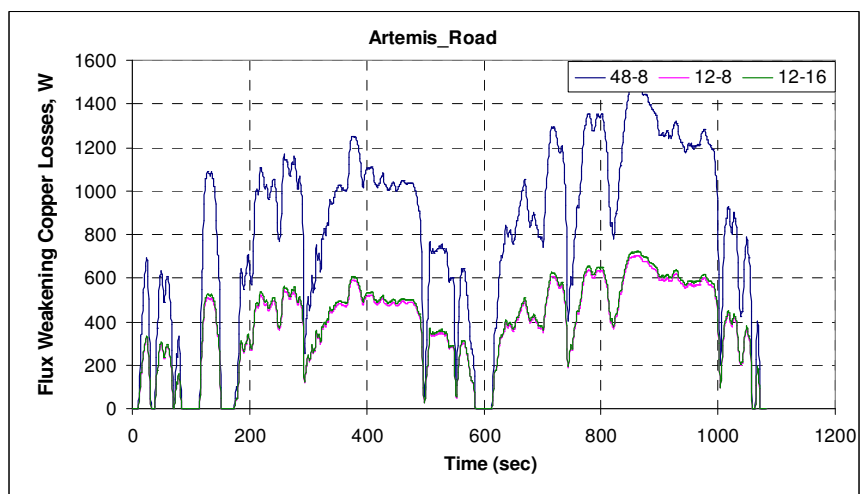

Fig.15.c. Flux weakening copper losses for the Artemis_Road driving cycle.

TABLE VIII

Average Flux WeAKENING COPPER Losses Result

\begin{tabular}{cccc}
\hline \hline $\begin{array}{c}\text { Average flux weakening copper } \\
\text { losses, W }\end{array}$ & $48-8$ & $12-8$ & $12-16$ \\
\hline NEDC & 395 & 185 & 191 \\
Artemis_Urban & 131 & 61 & 63 \\
Artemis_Road & 801 & 376 & 387 \\
\hline \hline
\end{tabular}

\section{COMPARATIVE STUdy OF THE AVERAGE LOSSES DURING THE DRIVING CYCLES OF HEV}

The part III has presented the calculation method of average losses during the driving cycle of $\mathrm{HEV}$, including the copper losses, the iron losses and the flux weakening copper losses. The computation result has been shown in Table IX that gives the global view and comparison during the driving cycles of vehicle. Therefore, the important variables of the optimal machine choice for this application have been developed such as the average losses during the driving cycles of vehicle.

TABLE IX

Average Losses During THE CyCles For $B_{R}=1.2 T$

\begin{tabular}{|c|c|c|c|c|c|}
\hline Machine & Cycle & $\begin{array}{c}\text { L_co, } \\
\text { W }\end{array}$ & $\begin{array}{c}\text { L_iron, } \\
\text { W }\end{array}$ & $\frac{{ }_{\text {L_co_flux_weekening, }}}{\mathrm{W}}$ & $\begin{array}{c}\text { L_tot, } \\
\mathrm{W}\end{array}$ \\
\hline \multirow[t]{3}{*}{$48-8$} & NEDC & 50 & 690 & 395 & 1135 \\
\hline & Urban & 102 & 241 & 131 & 474 \\
\hline & Road & 63 & 1260 & 801 & 2124 \\
\hline \multirow[t]{3}{*}{$12-8$} & NEDC & 22 & 760 & 185 & 967 \\
\hline & Urban & 44 & 262 & 61 & 367 \\
\hline & Road & 27 & 1391 & 376 & 1794 \\
\hline \multirow[t]{3}{*}{$12-16$} & NEDC & 10 & 1886 & 191 & 2087 \\
\hline & Urban & 16 & 610 & 63 & 689 \\
\hline & NEDC & 11 & 3477 & 387 & 3875 \\
\hline
\end{tabular}

According to Table IX, we have found some remarkable values of average losses during the cycle. In fact, the machine with 12slots-8poles gives the lowest losses during the three cycles. However, from the calculated losses contributions, we have found that the iron losses take an important part. That's why the improvement of the machine efficiency requires the reduction of iron losses. A resolution which we offered is to reduce the remanent flux density at $\mathrm{B}_{\mathrm{r}}=0.6 \mathrm{~T}$ giving the torque and speed capacity. With the new value of $B_{r}$, we have made the same calculation in case of $B_{r}=1.2 T$. And finally, we have obtained the result shown in the following table. 
TABLE X

Average Losses DuRING THE CYCLES FOR $B_{R}=0.6 \mathrm{~T}$

\begin{tabular}{|c|c|c|c|c|c|}
\hline Machine & Cycle & $\begin{array}{c}\text { L_co, } \\
\text { W }\end{array}$ & $\begin{array}{c}\text { L_iron, } \\
\text { W }\end{array}$ & L_co_flux_weekening, & L_tot, \\
\hline \multirow[t]{3}{*}{$48-8$} & NEDC & 264 & 323 & 73 & 660 \\
\hline & Urban & 592 & 112 & 24 & 728 \\
\hline & Road & 349 & 591 & 49 & 989 \\
\hline \multirow[t]{3}{*}{$12-8$} & NEDC & 152 & 181 & 35 & 368 \\
\hline & Urban & 344 & 66 & 12 & 422 \\
\hline & Road & 202 & 327 & 71 & 600 \\
\hline \multirow[t]{3}{*}{$12-16$} & NEDC & 24 & 476 & 37 & 537 \\
\hline & Urban & 46 & 162 & 12 & 220 \\
\hline & Road & 30 & 872 & 75 & 977 \\
\hline
\end{tabular}

According to Table IX and Table $\mathrm{X}$, although the copper losses have augmented, the iron losses and the flux weakening copper losses have much reduced. That is why the average losses during the cycle for the $\mathrm{B}_{\mathrm{r}}=0.6 \mathrm{~T}$ is lower than for the $\mathrm{B}_{\mathrm{r}}=1.2 \mathrm{~T}$ for all three machines.

Finally, in terms of average losses during the cycles, we have found that:

1) For the NEDC driving cycle, the $12-8$ machine gives the lowest losses.

2) For the Artemis_Urban driving cycle, the 12-16 machine gives the lowest losses.

3) For the Artemis_Road driving cycle, the 12-8 machine gives the lowest losses.

However, a vehicle works all its life not only for one kind of application (one cycle) but may for all three kinds of application (three cycles). Thus, we were interested to determinate the average losses during the three driving cycles of HEV.

TABLE XI

Average Losses During THE THREe CYCLES For $B_{\mathrm{R}}=0.6 \mathrm{~T}$

\begin{tabular}{ccc}
\hline \hline Machine & Average total losses, $\mathrm{W}$ & Average efficiency, \% \\
\hline $48-8$ & 792 & 90 \\
$12-8$ & $\mathbf{4 6 3}$ & $\mathbf{9 3 . 8}$ \\
$12-16$ & 578 & 92.4 \\
\hline \hline
\end{tabular}

Table XI has shown that the $12-8$ machine and with $\mathrm{B}_{\mathrm{r}}=0.6 \mathrm{~T}$ gives the lowest losses during the three driving cycles of vehicle. Then, the use of this machine gives better performance for this application than two others with the average efficiency of $93.8 \%$.

\section{CONCLUSIONS}

In this paper, three PMSMs with concentrated flux have been studied, two with the concentrated and fractional slot windings and the other with distributed windings.

This paper has presented the calculation method of average losses during the driving cycles of HEV, including the copper losses, the iron losses and the flux weakening copper losses. It can be considered as a criterion to compare the performances of machines and to choose the machine for this application.
In the case of our limited study in this paper, in terms of the average losses during the three cycles of HEV, the PMSMs with 12 slots-8poles and with magnet of $\mathrm{B}_{\mathrm{r}}=0.6 \mathrm{~T}$ may be considered as the best machine for this kind of application.

However, in this study, we have used some assumptions to simplify the iron losses computation. Thus, in the future works, the iron losses at load and the thermal problem will be studied to complete the comparative study of the three machines for this application.

\section{ACKNOWLEDGMENT}

This work was supported in part by the PREDIT MEEI project from French National Agency of Research (ANR), the ADEME, VALEO Electric Systems and LEROY SOMER.

\section{REFERENCES}

[1] Franz Zurcher, Thomas Nussbaumer, Wolfgang Gruber, Johann W.Kolar, "Design and development of a 26-pole and 24-slot bearingless motor", IEEE-INTERMAG 2009, Sacramento, California, USA, May 4-8, 2009.

[2] J. A. Guemes, A. M. Iraolagoitia, M. P. Donsion and J. I. Del Hoyo, "Analysis of Torque in Permanent Magnet Synchronous Motors with Fractional Slot Windings", ICEM 2008, Vilamoura, Portugal, Sept. 6-9, 2008, paper ID 1181.

[3] S. E. Skaar, O. Krovel, R. Nilssen, "Distribution, coil-span and winding factors for PM machines with concentrated windings", ICEM 2006, Chania, Crete Island, Greece, Sept. 2-5, 2006.

[4] Z. Q. Zhu, H. David, "Electrical Machines and Drives for Electric, Hybrid, and Fuel Cell Vehicles", Proceedings of the IEEE, vol. 95, No. 4, pp. 746-765, April 2007.

[5] J. Saint-Michel, "Electric machines for hybrid vehicles applications", AEAe2006, 5-6 April 2006, Poitiers, Futuroscope, France.

[6] Jérome Cros, Philippe Viarouge, "Synthesis of High Performance PM Motors With Concentrated Windings", IEEE Transactions on Energy Conversion, vol. 17, No. 2, pp. 248-253, June 2002.

[7] Amara Y., Vido L., Gabsi M., Hoang E., Lécrivain M., Chabot F. "Hybrid Excitation Synchronous Machines: Energy Efficient Solution for Vehicle Propulsion", IEEE VPPC Conference, Windsor, England, UK, September 2006.

[8] Ayman M. EF-Refaie, Thomas M. Jahns, "Optimal Flux Weakening in Surface PM Machines Using Fractional-Slot Concentrated Windings", IEEE Transactions on Industry Applications, vol. 41, No. 3, pp. 790800, May/June 2005.

[9] Christos Mademlis, Jannis Xypteras and Nikos Margaris, "Loss Minimization in Surface Permanent-Magnet Synchronous Motor Drives,' IEEE Transactions on Industrial Electronics, vol. 47, no. 1, pp. 115-122, February 2000.

[10] Christos Mademlis and Nikos Margaris, "Loss Minimization in Vector-Controlled Interior Permanent-Magnet Synchronous Motor Drives," IEEE Transactions on Industrial Electronics, vol. 49, no. 6, pp. 1344-1347, December 2002.

[11] L. Xu, L. Ye, L. Zhen and A. El-Antably, "A New Design Concept of Permanent Magnet Machine for Flux Weakening Operation", IEEE Transactions on Industry Applications, vol.31, No.2, March/April 1995, pp. 373-378.

[12] W. L. Soong and N. Ertugrul, "Field-Weakening Performance of Interior Permanent-Magnet Motors,' IEEE Transactions on Industry Applications, vol. 38, no. 5, pp. 1251-1258, Sep./Oct. 2002.

[13] O. Krovel, R. Nilssen, S. E. Skaar, E. Lovli, N. Sandoy, "Design of an Intergrated $100 \mathrm{~kW}$ Permanent Magnet Synchronous Machine in a Prototype Thruster for Ship Propulsion", ICEM 2004, Cracovie, Poland, Sept. 6-8, 2004. 